\title{
STRATEGI PENGELOLAAN NON PERFORMING LOAN BANK UMUM YANG GO PUBLIC
}

\section{Selamet Riyadi, Muhammad Iqbal, $₫$ Novia Lauren}

Fakultas Bisnis, Perbanas Institute, Jakarta, Indonesia

\section{Info Artikel}

Sejarah Artikel:

Diterima Januari 2015

Disetujui Januari 2015

Diterbitkan Maret 2015

\section{Keywords:}

non-performing loans;

capital adequacy ratio;

loan to deposit ratio;

panel random effects

\section{Abstrak}

Penelitian ini bertujuan untuk menganalisis pengaruh capital adequacy ratio, total aset, loan to deposit ratio, kualitas aktiva produktif dan biaya operasional terhadap pendapatan operasional terhadap non performing loan pada Bank Umum di Bursa Efek Indonesia periode tahun 2007 sampai dengan tahun 2014. Sampel yang digunakan dalam penelitian ini adalah 10 Bank Umum di BEI. Penelitian ini menggunakan metode regresi data panel dengan efek random. Hasil penelitian menyimpulkan bahwa capital adequacy ratio, loan to deposit ratio, kualitas aktiva produktif dan biaya operasional terhadap pendapatan operasional berpengaruh signifikan terhadap non performing loan, sedangkan variabel total aset tidak berpengaruh signifikan terhadap non performing loan. Model efek random layak digunakan untuk mengestimasi pengaruh capital adequacy ratio, total aset, loan to deposit ratio, kualitas aktiva produktif dan biaya operasional terhadap pendapatan operasional terhadap non performing loan.

\section{MANAGING THE NON PERFORMING LOAN OF LISTED BANKS}

\begin{abstract}
This study aimed to analyze the effect of capital adequacy ratio, total asets, loan to deposit ratio, asset quality and operating expenses to operating income on non-performing loans at commercial banks in Indonesia Stock Exchange period 2007 to 2014. The sample used in this study is the 10 commercial banks listed in IDX. This study uses panel data regression with random effect. The study concluded that the capital adequacy ratio, loan to deposit ratio, asset quality and operating expenses to operating income have a significant effect on nonperforming loans, while total asets variable has no significant effect on non-performing loans. Random effects model was used to estimate the effect deserves its capital adequacy ratio, total asets, and loan to deposit ratio, asset quality and operating expenses to operating income on non-performing loans.
\end{abstract}

JEL Classification: G1, G11

\footnotetext{
Alamat korespondensi :

Jalan Perbanas, Karet Kuningan, Setiabudi, Jakarta 12940 Jalan Bukit Dago Utara No. 25 Bandung

E-mail: iqbal@perbanas.id

Telp. 021-5252533 Ext.5200
} 
Selamet Riyadi, Muhammad Iqbal, Novia Lauren / Strategi Pengelolaan Non Performing Loan (NPL)...

\section{PENDAHULUAN}

Bank merupakan suatu badan usaha yang tugas utamanya sebagai lembaga perantara keuangan, yang menyalurkan dana dari pihak yang berkelebihan dana kepada pihak yang membutuhkan dana atau kekurangan dana pada waktu yang ditentukan (Dendawijaya, 2009). Bank menghimpun dana dari masyarakat dalam bentuk simpanan dan menyalurkannya kepada masyarakat dalambentuk kreditdanataubentukbentuk lainnya, dalam rangka meningkatkan taraf hidup masyarakat banyak (UU No.7/92 dan UU No.10/98). Pendapat lain menyatakan bank adalah badan usaha yang menghimpun dana dari masyarakat dalam bentuk simpanan dan menyalurkannya kepada masyarakat dalam bentuk kredit dan atau bentuk-bentuk lainnya dalam rangka meningkatkan taraf hidup rakyat banyak (Loen \& Ericson, 2007). Berdasarkan pendapat diatas maka dapat disimpulkan bahwa bank merupakan lembaga keuangan yang menghimpun dana dari masyarakat dan menyalurkannya kepada masyarakat terutama dalam bentuk kredit serta memberikan jasa-jasa perbankan baik dalam maupun luar negeri.

Terdapat dua jenis bankyaitu Bank Umum dan Bank Perkreditan Rakyat (UU No.10/98). Bank Umum adalah bank yang melaksanakan kegiatan usaha secara konvensional dan atau berdasarkan prinsip syariah yang dalam kegiatannya memberikan jasa dalam lalu lintas pembayaran. Kegiatan utama bank umum, selain menghimpun dana dari masyarakat yang memiliki kelebihan dana juga menyalurkan dana tersebut kepada masyarakat yang membutuhkan dana dalam bentuk kredit atau pembiayaan. Penyaluran dana dalam bentuk kredit saat ini berkisar antara 78\% sampai 98\% (Bank Indonesia, 2013) dari jumlah dana masyarakat yang dihimpun bank. Setiap kredit yang diberikan tidak lepas dari berbagai risiko yang dapat mengancam kesehatan bank. Non Performing Loan (NPL) merupakan ukuran risiko kredit yang menjadi parameter tingkat kesehatan bank. Bank dinilai memiliki potensi kesulitan yang membahayakan kelangsungan usahanya jika rasio kredit bermasalah (Non Performing Loan) secara neto lebih dari 5\% dari total kredit (PBI15/2/PBI/2013). Jika melebihi $5 \%$ maka akan mempengaruhi penilaian tingkat kesehatan bank tersebut. Semakin besar tingkat NPL maka banktersebut tidak profesional dalam pengelolaan kreditnya, sekaligus memberikan indikasi bahwa tingkat risiko atas pemberian kredit pada bank tersebut cukup tinggi searah dengan tingginya NPL (Riyadi, 2006).

Meskipun rata-rata rasio NPL tidak melebihi angka 5\%, seperti terlihat pada Gambar 1, tetapi nilainya relatif berfluktuasi. Hal ini menunjukkan bahwa NPL rentan sekali mengalami perubahan yang tidak terduga. Oleh karena itu, diperlukan suatu strategi yang tepat dalam mengendalikan rasio NPL agar kinerja Bank Umum yang go public jauh lebih baik sehingga mendorong investor tertarik

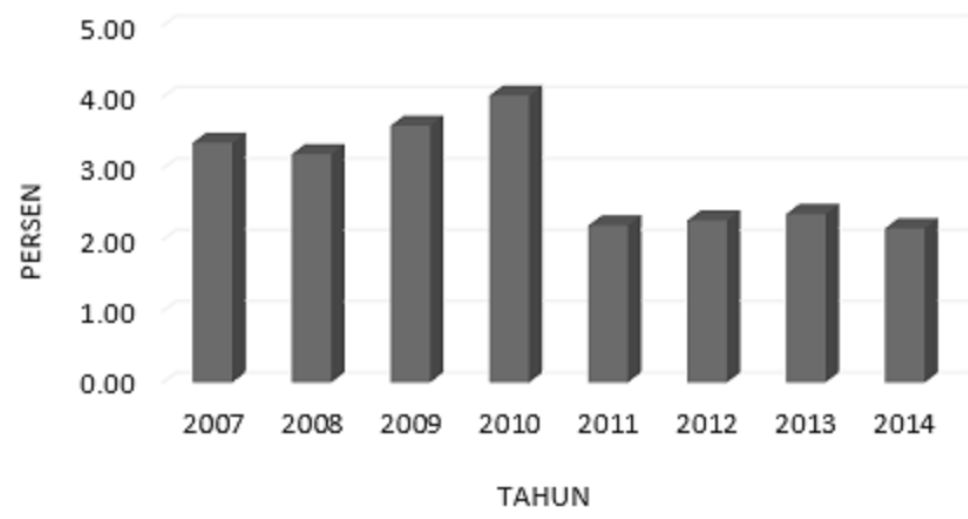

Gambar 1. Rata-rata NPL Bank Umum yang Go Public 
berinvestasi. Salah satu cara pengendalian NPL adalah dengan mengetahui faktor-faktor yang dominan mempengaruhi NPL. Diketahuinya faktor-faktor yang memperngaruhi NPL diharapkan dapat menjadi masukan bagi manajemen Bank Umum agar dapat menekan tingginya NPL, terutama pada kondisi-kondisi krisis ekonomi.

Dengan mengetahui rasio NPL suatu bank, masyarakat dan Bank Indonesia dapat mengambil langkah yang bijak dalam menyikapi dan menghadapi bank tersebut. Peningkatan atau penurunan rasio NPL pada suatu bank dapat dipengaruhi oleh berbagai faktor, baik internal bank, maupun secara makro. Secara kuantitatif, faktor-faktor yang mempengaruhi NPL dapat berupa capital adequacy ratio (CAR), total aset, loan to deposit ratio (LDR), kualitas aktiva produktif (KAP), biaya operasional terhadap pendapatan operasional (BOPO), jumlah pembiayaan/kredit dan profitabilitas bank. Selain itu, ada juga faktor lain yang menyebabkan terjadinya kredit bermasalah, seperti: proses analisis kredit yang buruk, produk gagal yang ditawarkan kepada nasabah, pinjaman berdasarkan kekuatan neraca bukan berdasarkan pinjaman arus kas, bank mengambil terlalu banyak kenyamanan dalam keamanan, asimetri informasi yang mengarah ke moral hazard, lingkungan ekonomi dan pengaruh politik (Chikoko et al., 2012; Hapsari, 2012). Secara makro ekonomi, penyebab utama tingginya tingkat NPL adalah perlambatan ekonomi, yang terlihat dari koefisien yang signifikan secara statistik dan ekonomi yang besar pada $\mathrm{PDB}$, pengangguran dan tingkat inflasi (Skarica, 2014).

\section{Kajian Pustaka}

Kredit adalah pinjaman yang diberikan olehbankataupenyediaanuangatau tagihanyang dapat dipersamakan dengan itu, berdasarkan persetujuan atau kesepakatan pinjam meminjam antara bank dengan pihak lain yang mewajibkan penerima pinjaman (debitur) untuk melunasi utangnya setelah jangka waktu tertentu dengan pembayaran bunganya (Riyadi, 2006). Kredit adalah penyediaan uang atau tagihan yang dapat dipersamakan dengan itu, berdasarkan kesepakatan pinjam meminjam antara pihak bank dengan pihak lain yang mewajibkan pihak peminjam untuk melunasi hutangnya setelah jangka waktu tertentu dengan pemberian bunga (UU No.10/98). Pengertian lainnya, kredit adalah penyediaan uang atau tagihan yang dapat dipersamakan dengan itu, berdasarkan persetujuan atau kesepakatan pinjam meminjam antara bank dengan pihak lain yang mewajibkan pihak peminjam untuk melunasi hutangnya setelah jangka waktu tertentu dengan pemberian bunga (Siamat, 2005). Dengan demikian kredit adalah pinjaman yang diberikan oleh bank kepada debiturnya.

Kualitas kredit dikelompokan menjadi 5, yaitu: lancar (L), dalam perhatian khusus (DPK), kurang lancar (KL), diragukan (D) dan macet (M) (Dendawijaya, 2009). Oleh karena itu, kualitas kredit harus diperhatikan karena jika terjadi banyak kredit bermasalah maka akan merugikan bank itu sendiri. Kredit bermasalah (Riyadi, 2006) merupakan kredit yang digolongkan ke dalam kolektibilitas Kurang Lancar (KL), Diragukan (D) dan Macet (M). Kredit bermasalah atau risiko kredit dapat diketahui dari rasio non performing loan (NPL). NPL dihitung berdasarkan perbandingan antara jumlah kredit yang diberikan dengan kolektibilitas kurang lancar, diragukan, dan macet dibandingkan dengan total kredit (Riyadi, 2006). Besar kecilnya jumlah kredit yang diberikan bank akan mempengaruhi penyaluran NPL di suatu bank. Besarnya rasio NPL dapat dihitung dengan rumus (Riyadi, 2006):

$$
\mathrm{NPL}=\frac{\begin{array}{c}
\text { kredit yang diberikan } \\
\text { dengan kal } \frac{3 \mathrm{~s}}{\mathrm{~d} 5} \mathrm{PPAP} \frac{3 \mathrm{~s}}{\mathrm{~d} 5}
\end{array}}{\text { total kredit yang diberikan }} \times 100 \%
$$

Rasio capital adequacy ratio (CAR) memperlihatkan kecukupan modal yang dimiliki bank untuk menunjang aktiva yang mengandung risiko, misalnya kredit yang 
diberikan (Dendawijaya, 2009). Rasio CAR diperoleh dari perbandingan antara modal yang dimiliki dengan Aktiva Tertimbang menurut Risiko (ATMR) (Riyadi, 2006). Besarnya nilai rasio CAR dapat dihitung dengan rumus (Dendawijaya, 2009):

$$
\mathrm{CAR}=\frac{\text { Modal Bank }}{\text { Aktiva Tertimbang }}
$$

Penurunan jumlah CAR merupakan akibat dari menurunnya jumlah modal bank atau meningkatnya jumlah Aktiva Tertimbang Menurut Risiko (ATMR). CAR mempunyai pengaruh negatifterhadap NPL (Soebagio, 2005), (Diyanti \& Widyarti, 2012) dan (Makri et al., 2014). Semakin tinggi CAR maka akan semakin kecil NPL. Penelitian Wardoyo dan Rusdiyanti (2009), Jusmansyah dan Sriyanto (2013) dan Vatansever dan Hepsen (2015) mengungkapkan bahwa CAR berpengaruh positif terhadap NPL. Semakin tinggi CAR maka akan semakin tinggi pula NPL. Berdasarkan uraian diatas maka dapat disusun hipotesis berikut:

$\mathrm{H}_{1}$ : Capital adequacy ratio berpengaruh signifikan terhadap non performing loan

Aset disebut juga aktiva, sisi aktiva pada bank menunjukkan strategi dan kegiatan manajemen yang berkaitan dengan tempat pengumpulan dana meliputi kas, rekening pada bank sentral, pinjaman jangka pendek dan jangka panjang, dan aktiva tetap. Total Aset suatu bank dapat menggambarkan jumlah kredit yang dapat disalurkan. Bank dengan aset yang besar mampu menghasilkan keuntungan lebih besar apabila diikuti dengan hasil dari aktivitas operasional bank tersebut (Jayanti \& Haryanto, 2013). Ukuran bank yang diproksikan total aset berpengaruh positif terhadap NPL (Zaib et al., 2014). Semakin besar kredit yang disalurkan maka dapat berdampak pada meningkatnya kredit bermasalah (Jayanti \& Haryanto, 2013). Besarnya aktiva atau asset yang dimiliki suatu bank menunjukan volume kredit yang dapat disalurkan oleh bank tersebut, ukuran bank yang diproksikan total aset berpengaruh negatif terhadap NPL (Diyanti \& Widyarti, 2012; Abedalfattah \& Faris, 2013; Polodoo et al., 2015). Berdasarkan uraian diatas maka dapat disusun hipotesis berikut:

$\mathrm{H}_{2}$ : Total aset berpengaruh signifikan terhadap non performing loan

Besarnya jumlah kredit yang disalurkan dapat diketahui dari rasio loan to deposit ratio (LDR) sebuah bank, karena LDR merupakan rasio antara jumlah kredit yang diberikan bank dengan jumlah dana pihak ketiga yang diterima oleh bank. Rasio ini menunjukkan kemampuan bank dalam membayar kembali penarikan dana yang dilakukan deposan dengan mengandalkan kredit yang diberikan sebagai sumber pendapatannya. Menurut ketentuan Bank Indonesia maksimal LDR yang diperkenankan saat ini adalah sebesar 92\%. Rasio LDR dapat dirumuskan sebagai berikut (Riyadi, 2006):

$$
\mathrm{LDR}=\frac{\begin{array}{c}
\text { Total Kredit } \\
\text { yang Diberikan }
\end{array}}{\text { Total DPK }} \times 100 \%
$$

Penyaluran kredit merupakan kegiatan utama bank, oleh karena itu sumber pendapatan utama bank berasal dari kredit. Semakin besar kredit yang salurkan dibandingkan dengan simpanan masyarakat pada suatu bank membawa konsekuensi bahwa semakin besar risiko yang harus ditanggung oleh bank yang bersangkutan (Diyanti \& Widyarti, 2012; Jayanti \& Haryanto, 2013; Abedalfattah \& Faris, 2013; Akinlo \& Emmanuel, 2014). Bertentangan dengan hasil penelitian Soebagio (2005) bahwa LDR memiliki pengaruh negatif terhadap NPL. Berdasarkan uraian diatas maka dapat disusun hipotesis berikut:

$\mathrm{H}_{3}$ : Loan to deposit ratio berpengaruh signifikan terhadap non performing loan

Guna mengetahui probabilitas kegagalan kredit maka perlu diketahui kualitas aktiva produktif (KAP). KAP merupakan rasio antara aktiva produktif yang diklasifikasikan (APYD) terhadap total aktiva produktif. APYD 
terdiri dari kredit dalam perhatian khusus, kredit kurang lancar, kredit diragukan, dan kredit macet (Riyadi, 2006). Rasio KAP dapat dirumuskan sebagai berikut:

$$
\mathrm{KAP}=\frac{\begin{array}{c}
\text { Aktifa Produktif } \\
\text { yang Dikalrifikasikan }
\end{array}}{\text { Aktifa Produktif }} \times 100 \%
$$

Meningkatnya rasio KAP dipengaruhi oleh meningkatnya APYD atau menurunnya total aktiva produktif. Jika APYD meningkat artinya kredit dalam perhatian khusus, kredit kurang lancar, kredit diragukan, dan kredit macet juga meningkat. Dengan demikian, jika rasio KAP tinggi berarti tingkat kredit macet atau bermasalah juga tinggi. Hal tersebut didukung penelitian yang dilakukan Soebagio (2005) dan Jayanti dan Haryanto (2013) bahwa KAP berpengaruh positif terhadap NPL. Berdasarkan uraian diatas, maka dapat disusun hipotesis berikut:

$\mathrm{H}_{4}$ : Kualitas aktiva produktif berpengaruh signifikan terhadap non performing loan

BOPO adalah rasio perbandingan antara Biaya Operasional dengan Pendapatan Operasional (Riyadi, 2006). Rasio BOPO disebut sebagai rasio efisiensi yang digunakan untuk mengukur kemampuan manajemen bank dalam mengendalikan biaya operasional terhadap pendapatan operasional dalam kegiatan operasionalnya. Besarnya rasio BOPO yang dapat ditolerir oleh perbankan di Indonesia adalah sebesar 93, 52\%. BOPO dapat dirumuskan sebagai berikut (Loen \& Ericson, 2007).

Menurut Jayanti dan Haryanto (2013), kemungkinan gagal bayar dari debitur dapat menimbulkan biaya tambahan atas penagihan yang dikategorikan sebagai kerugian. Penelitian Ngadlan dan Riadi (2010) mengatakan bahwa biaya operasional terhadap pendapatan operasional (BOPO) digunakan untuk mengukur efisiensi dan efektivitas operasional suatu perusahaan. Semakin kecil rasio BOPO berarti semakin efisien biaya operasional yang dikeluarkan bank sehingga kemungkinan bank dalam kondisi bermasalah semakin kecil. Hal ini sejalan dengan penelitian yang dilakukan oleh (Jayanti dan Haryanto (2013) dan Wardoyo dan Rusdiyanti (2009) bahwa BOPO berpengaruh positif terhadap NPL. Sedangkan Vatansever dan Hepsen (2015) berpengaruh negatif terhadap NPL. Berdasarkan uraian diatas, maka dapat disusun hipotesis berikut:

$\mathrm{H}_{5}$ : BOPO berpengaruh signifikan terhadap non performing loan

Variabel pengamatan meliputi Capital Adequacy Ratio (CAR), Total Aset, Loan to Deposit Ratio (LDR), Kualitas Aktiva Produktif (KAP), Biaya Operasional terhadap Pendapatan Operasional (BOPO) dan Non Performing Loan (NPL). Ada dua tujuan

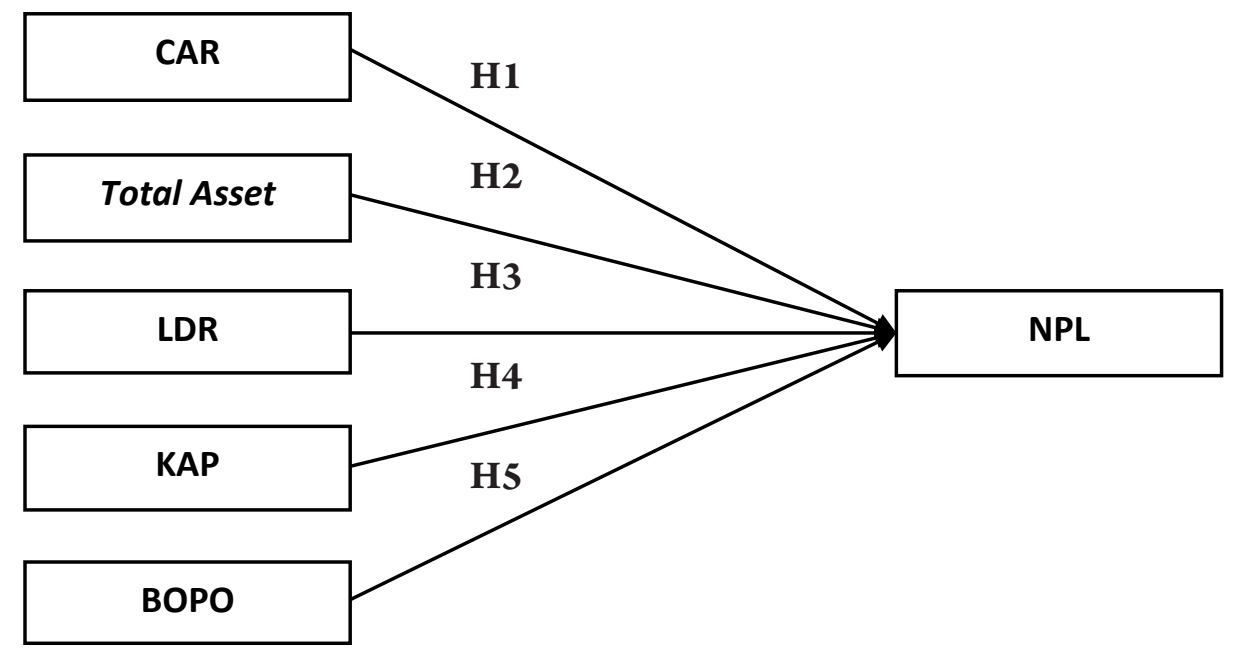

Gambar 2. Kerangka Berpikir 
yang akan dicapai. Pertama, memahami dan menganalisis pengaruh CAR, Total Aset, LDR, KAP, dan BOPO terhadap NPL dan strategi pengelolaannya pada bank umum. Kedua, mencari peran CAR, Total aset, LDR, KAP, dan BOPO dalam model yang layak guna menjelaskan strategi pengelolaan NPL pada Bank Umum.

\section{METODE}

Jenis penelitian yang digunakan adalah penelitian kuantitatif dengan metode asosiatif. Menurut Kuncoro (2009) uji asosiatif merupakan penelitian yang pada dasarnya bertujuan untuk mengetahui hubungan antara dua variabel atau lebih, serta korelasi yang ada di antara variabel yang di teliti. Menurut Sugiyono (2009) menyatakan data kuantitatif adalah data yang berbentuk angka atau data kualitatif yang diangkakan.

Populasi yang digunakan sebagai sampel dalam penelitian ini adalah 33 Bank Umum di Bursa Efek Indonesia periode 2007-2014. Teknik sampel yang digunakan dalam penelitian ini dengan metode purposive sampling, yaitu teknik penentuan sampel dengan pertimbangan atau kriteria tertentu (Sugiyono, 2013). Metode pengambilan sampel dengan menggunakan metode pengambilan purposive sampling tujuannya agar peneliti mendapatkan sampel yang sesuai dengan yang diinginkan peneliti, sehingga mudah untuk dilakukan penelitiannya. Kriteria yang digunakan dalam penentuan sampel penelitian meliputi: Bank Umum di Bursa Efek Indonesia periode 2007-2014. Bank Umum di Bursa Efek Indonesia yang dalam laporan keuangannya terdapat rasio yang dibutuhkan dalam penelitian periode 2007-2014. Sepuluh Bank Umum yang mempunyai asset terbesar dan terdaftar di Bursa Efek Indonesia.

Salah satu alasan penggunaan objek penelitian Bank Umum yang ada di Bursa Efek Indonesia karena sumber utama pendapatan Bank Umum adalah berasal dari kredit dan pendanaan terhadap kerugian akibat risiko yang timbul dari kredit sepenuhnya harus ditanggung sendiri tanpa melibatkan nasabah sehingga membuat Bank Umum lebih rentan terkena kredit bermasalah. Bank umum di Bursa Efek Indonesia adalah bank yang melaksanakan kegiatan usaha menghimpun dana masyarakat dan menyalurkan dana kepada masyarakat dalam bentuk kredit serta memberikan jasa dalam lalu lintas pembayaran dan bank tersebut menjual sebagian sahamnya kepada publik di Bursa Efek Indonesia.

Penelitian ini menggunakan metode regresi data panel karena data yang digunakan berupa data panel. Data panel adalah gabungan data cross section dan time series. Penelitian ini menggunakan data panel karena objek penelitiannya terdiri dari 10 bank umum di Bursa Efek Indonesia periode 2007-2014 dalam bentuk laporan triwulan publikasi. Pada penelitian ini, peneliti melakukan pengolahan data dan perhitungan dengan menggunakan bantuan software alat pengolahan data kuantitatif berupa program Microsoft Excel versi 2010 dan Eviews versi 8.0.

Estimasi regresi data panel terdapat tiga model yaitu common effect, fixed effect dan random effect. Penelitian Nachrowi dan Usman (2006) menjelaskan bahwa teknik common effect hanya dengan mengkombinasi data cross section atau time series. Dalam data panel, sebelum membuat regresi ada keharusan menggabungkan data cross section dengan time series atau dapat disebut dengan pool data. Kemudian data gabungan ini diperlukan sebagai suatu kesatuan pengamatan yang digunakan untuk estimasi model dengan metode ordinary least square.

Penggunaan variabel dummy untuk menangkap adanya perbedaan intersep merupakan teknik pendekatan fixed effect. Hal tersebut didasarkan adanya perbedaan intersep antar perusahaan namun intersepnya sama antar waktu. Selain itu, terdapat juga asumsi koefisien regresi (slope) tetap antar perusahaan dan antar waktu dalam model pendekatan ini. Model random effect menggambarkan perbedaan karakteristik individu dan waktu dengan error model (Nachrowi dan Usman, 2006). Karena ada dua komponen yang mempunyai kontribusi 
pada pembentukan error, yaitu individu dan waktu, maka random error pada metode efek random juga perlu diurai menjadi error untuk komponen individu, error komponen waktu dan error gabungan. Pemilihan model terbaik ditentukan dengan melakukan uji Chow, uji Lagrange Multiplier dan uji Hausman (Widarjono, 2013).

Analisis kelayakan model regresi data panel meliputi uji koefisien regresi (uji $t$ ), uji keterandalan model (uji F) dan analisis koefisien determinasi (adjusted $\mathrm{R}^{2}$ ). Uji t atau uji signifikansi parsial digunakan untuk mengetahui pengaruh variabel independen secara parsial terhadap variabel dependen. Sedangkan Uji $F$ atau uji simultan digunakan untuk menguji pengaruh variabel independen secara bersamasama terhadap variabel dependen (Priyatno, 2011). Analisis koefisien determinasi digunakan untuk melihat persentase pengaruh variabel independen terhadap variabel dependen. Koefisien determinasi untuk regresi dengan lebih dari dua variabel bebas disarankan untuk menggunakan adjusted $\mathrm{R}^{2}$.

\section{HASIL DAN PEMBAHASAN}

Terdapat tiga model estimasi regresi data panel yaitu common effect, fixed effect, dan random effect. Untuk mengetahui model mana yang dipakai, maka dilakukan beberapa pengujian terlebih dahulu. Setelah itu model yang terpilih dapat digunakan untuk mengintepretasikan pengaruh variabel-variabel CAR, Total aset, LDR, KAP, dan BOPO terhadap NPL, sehingga pengelolaan terhadap kredit macet dapat dilakukan dengan strategi yang tepat. Berikut akan diuraikan hasil dari ketiga model estimasi tersebut.

Hasil estimasi model regresi dengan menggunakan pendekatan ordinary least square atau common effect disajikan pada Tabel 2. Model common effect hanya memiliki nilai adjusted $\mathrm{R}^{2}$ sebesar 0,4642 . Pada model common effect koefisien determinasi yang diukur dengan adjusted $\mathrm{R}^{2}$ ini tidaklah besar nilainya. Hal ini mengindikasikan bahwa variasipengaruh Capital Adequacy Ratio (CAR), Total aset (TA), Loan to Deposit Ratio (LDR), Kualitas Aktiva produktif (KAP), dan Biaya Operasional Pendapatan Operasional (BOPO) terhadap Non Performing Loan (NPL) tidak lebih dari setengahnya, hanya $46,42 \%$. Artinya model dengan pendekatan common effect tidak cukup menjelaskan proporsi pengaruh variabel-variabel bebas terhadap variabel terikat NPL. Meskipun demikian, jika dilihat dari uji kelayakan model (Uji F), model tersebut tetap dikategorikan layak menjelaskan pengaruh variabel-variabel bebas terhadap variabel terikatnya. Hal ini terlihat dari nilai probabilitas $\mathrm{F}$ hitung yang lebih kecil dari tingkat error 0,05 pada Tabel 1 .

Tabel 1. Model Common Effect

\begin{tabular}{lcccc}
\hline \multicolumn{5}{c}{ Variabel Dependen: NPL } \\
\hline \multicolumn{1}{c}{ Variabel Independen } & Coefficient & Std. Error & t-Statistic & Prob. \\
\hline CAR & 0,072402 & 0,016882 & 4,288738 & 0,0000 \\
TA & $-0,429073$ & 0,251301 & $-1,707407$ & 0,0888 \\
LDR & 0,005222 & 0,003557 & 1,468399 & 0,1430 \\
KAP & 0,331937 & 0,045354 & 7,318829 & 0,0000 \\
BOPO & 0,037870 & 0,008488 & 4,461677 & 0,0000 \\
C & $-0,494689$ & 2,814358 & $-0,175773$ & 0,8606 \\
\hline Adjusted R-squared & 0,464178 & & & \\
F-statistic & 54,53671 & & & \\
Prob(F-statistic) & 0,000000 & & & \\
\hline Subidatyang
\end{tabular}

Sumber: data yang diolah (2015) 
Selamet Riyadi, Muhammad Iqbal, Novia Lauren / Strategi Pengelolaan Non Performing Loan (NPL)...

Capital Adequacy Ratio (CAR), Kualitas Aktiva produktif (KAP), dan Biaya Operasional. Pendapatan Operasional (BOPO) memiliki nilai probabilitas $t$ hitung yang lebih kecil dari tingkat error 0,05 sehingga dapat dikatakan bahwa ketiganya berpengaruh signifikan terhadap NPL. Ketiganya juga memiliki pengaruh searah terhadap NPL, sebagaimana ditunjukkan oleh nilai koefisien dari ketiga variabel yang positif. Pada saat CAR mengalami peningkatan maka NPL akan ikut meningkat dan sebaliknya, pada saat CAR menurun maka NPL juga akan menurun. Pada saat KAP naik maka NPL juga naik dan pada saat KAP turun maka NPL juga turun. Pada saat BOPO berkurang maka NPL juga akan berkurang dan sebaliknya, pada saat BOPO bertambah maka NPL juga akan bertambah.

Berbeda dengan ketiga variabel di atas, variabel Total aset (TA) dan Loan to Deposit Ratio (LDR) yang tidak berpengaruh signifikan terhadap NPL. Nilai probabilitas thitung keduanya lebih besar dari tingkat error 0,05 . Pada saat $\mathrm{TA}$ bertambah atau berkurang maka NPL relatif tidak akan mengalami perubahan yang berarti. Begitu pula dengan perubahan nilai LDR juga tidak akan mempengaruhi kenaikan atau penurunan rasio NPL.

Model common effect mengabaikan adanya keunikan dari data panel yang berasal dari beberapa bank, tidak hanya dari beberapa waktu yang berbeda. Model common effect mengganggap bahwa semua bank memiliki karakteristik yang sama padahal sangat dimungkinkan bahwa bank yang menjadi sampel memiliki karakteristik yang berbeda. Oleh karena itu diajukan dua model alternatif yang berbeda, yaitu model fixed effect dan model random effect. Keduanya memperhitungkan adanya keunikan dari masing-masing bank yang menjadi sampel penelitian.

Hasil estimasi model fixed effect (efek tetap) sebagaimana yang ditampilkan pada Tabel 2 menunjukkan nilai koefisien determinasi yang lebih besar dari nilai koefisien determinasi model common effect. Nilai adjusted $\mathrm{R}^{2}$ mencapai 0,6654. Ini artinya CAR, TA, LDR, KAP dan BOPO memiliki variasi pengaruh sebesar $66,54 \%$ terhadap NPL, sedangkan 33,46\% lainnya dipengaruhi oleh variasi variabel lain yang tidak diidentifikasi pada model fixed effect. Koefisien determinasi model fixed effect yang lebih besar dari model common effect mengindikasikan bahwa sesungguhnya terdapat perbedaan karakteristik NPL pada setiap bank umum yang Go Public. Dengan kata lain, perbedaan karakteristik bank ikut memberikan kontribusi terhadap semakin kuatnya pengaruh variabel-variabel bebas terhadap variabel terikatnya.

Nilai probabilitas F hitung yang lebih kecil dari nilai alpha 0,05 mengindikasikan bahwa model fixed effect layak digunakan untuk menjelaskan

Tabel 2. Model Fixed Effect

\begin{tabular}{lcccc}
\hline \multicolumn{5}{c}{ Variabel Dependen: NPL } \\
\hline \multicolumn{1}{c}{ Variabel Independen } & Coefficient & Std. Error & t-Statistic & Prob. \\
\hline CAR & 0,068699 & 0,015547 & 4,418741 & 0,0000 \\
TA & $-0,313166$ & 0,284573 & $-1,100477$ & 0,2720 \\
LDR & $-0,015683$ & 0,005732 & $-2,735780$ & 0,0066 \\
KAP & 0,187156 & 0,046236 & 4,047841 & 0,0001 \\
BOPO & 0,038323 & 0,008776 & 4,366962 & 0,0000 \\
C & 0,636432 & 2,668600 & 0,238489 & 0,8117 \\
\hline Adjusted R-squared & 0,663586 & & & \\
F-statistic & 44,88944 & & & \\
Prob(F-statistic) & 0,000000 & & & \\
Sumber: data yang diolah $(2015)$ & & &
\end{tabular}


pengaruh variabel CAR, TA, LDR, KAP dan BOPO terhadap NPL. Sehingga model fixed effect dapat dijadikan alternatif pilihan pada regresi data panel. Berbeda dengan model common effect, pada model fixed effect variabel yang berpengaruh signifikan terhadap NPL ada empat, yaitu Capital Adequacy Ratio (CAR), Loan to Deposit Ratio (LDR), Kualitas Aktiva Produktif (KAP), dan Biaya Operasional Pendapatan Operasional (BOPO). Hanya satu yang tidak berpengaruh signifikan, yaitu variabel Total aset (TA).

Hal ini ditunjukkan oleh nilai probabilitas dari $\mathrm{t}$ hitung untuk CAR, LDR, KAP dan BOPO yang lebih kecil dari 0,05. Sedangkan probabilitas t hitung TA lebih besar dari 0,05. LDR yang pada model common effect tidak berpengaruh signifikan, pada model fixed effect berpengaruh signifikan. Pengaruh LDR terhadap NPL berlawanan arah. Artinya, pada saat LDR meningkat maka NPL akan menurun dan sebaliknya. Sama halnya pada model common effect, pengaruh CAR, KAP dan BOPO pada model fixed effect searah.

Berdasarkan Tabel 3 dapat dilihat hasil adjusted $\mathrm{R}^{2}$ pada model random effect (efek random) lebih rendah dari common effect dan fixed effect, yaitu sebesar 0,37899. Meskipun demikian, model random effect memiliki tingkat kompleksitas yang lebih jika dibandingkan dengan kedua model sebelumnya. Pada model random effect selain dapat diidentifikasi adanya pengaruh dari perbedaan karakteristik bank, juga dapat diidentifikasi pengaruh variabel lain di luar model yang signifikan. Seperti dengan model common effect dan fixed effect, hasil uji $F$ model random effect juga mengindikasikan bahwa model layak digunakan untuk menjelaskan pengaruh variabel-variabel bebas CAR, TA, LDR, KAP dan BOPO terhadap variabel terikat NPL. Nilai probabilitas F hitung lebih kecil dari alpha 0,05.

Berdasarkan nilai probabilitas $\mathrm{t}$ hitung, pada model random effect variabel yang pengaruhnya signifikan adalah Capital Adequacy Ratio (CAR), Loan to Deposit Ratio (LDR), Kualitas Aktiva produktif (KAP), dan Biaya Operasional Pendapatan Operasional (BOPO) karena nilainya probabilitasnya lebih kecil dari alpha 0,05 . Sedangkan untuk variabel Total aset (TA) tidak berpengaruh signifikan. Hasil ini sama dengan yang diperoleh pada model fixed effect, baik dari segi jumlah variabel yang signifikan maupun dari segi arah pengaruhnya. Meskipun demikian, besar pengaruh setiap variabel bebas terhadap variabel terikat tetaplah berbeda antar model fixed effect dengan model random effect.

Berdasarkan hasil uji Chow dapat dilihat hasil F-hitung dan chi-square-nya yang lebih kecil dari nilai $\alpha(0,05)$ maka dapat disimpulkan

Tabel 3. Model Random Effect

\begin{tabular}{lcccc}
\hline \multicolumn{5}{c}{ Variabel Dependen: NPL } \\
\hline Variabel Independen & Coefficient & Std. Error & t-Statistic & Prob. \\
\hline CAR & 0,069160 & 0,015460 & 4,473452 & 0,0000 \\
TA & $-0,401629$ & 0,270085 & $-1,487050$ & 0,1380 \\
LDR & $-0,012243$ & 0,005242 & $-2,335420$ & 0,0202 \\
KAP & 0,192488 & 0,045605 & 4,220796 & 0,0000 \\
BOPO & 0,039945 & 0,008538 & 4,678267 & 0,0000 \\
C & 0,929434 & 2,636543 & 0,352520 & 0,7247 \\
\hline Adjusted R-squared & 0,378990 & & & \\
F-statistic & 38,71526 & & & \\
Prob(F-statistic) & 0,000000 & & \\
\hline Subidatang dis & & & \\
\hline
\end{tabular}

Sumber: data yang diolah (2015) 
Selamet Riyadi, Muhammad Iqbal, Novia Lauren / Strategi Pengelolaan Non Performing Loan (NPL)...

bahwa penggunaan model fixed effect lebih baik dalam mengestimasi regresi data panel dibandingkan dengan model ordinary least square atau common effect.

Pada Tabel 5 dapat dilihat nilai probabilitas dari chi-square sebesar 0,6447 lebih besar dari nilai $\alpha(0,05)$ maka dapat disimpulkan bahwa model random effect lebih baik digunakan dalam mengestimasi data panel dibandingkan dengan model fixed effect.

Berdasarkan hasil yang diperoleh dari kedua uji Chow dan uji Hausman pada Tabel 4 dan Tabel 5 dalam memilih model regresi data panel maka dapat disimpulkan bahwa model random effect adalah metode estimasi regresi data panel terbaik dalam penelitian ini. Karena random effect menggunakan metode GLS maka tidak perlu melakukan uji heteroskedastisitas.

Berdasarkan Tabel 3 diperoleh persamaan regresi data penelitian dengan pendekatan efek random adalah sebagai berikut:

$\mathrm{NPL}=0,9294+0,0692 \mathrm{CAR}-0,4016 \mathrm{AT}-$

$0,0122 \mathrm{LDR}+0,1925 \mathrm{KAP}+0,0399 \mathrm{BOPO}$

Berdasarkan hasil pengolahan data, nilai adjusted $\mathrm{R}^{2}$ adalah sebesar 0,378990 . Hal ini dapat diartikan bahwa variabel-variabel bebas
CAR, TA, LDR, KAP, dan BOPO berpengaruh terhadap NPL sebesar 37,9\% dan sisanya yaitu sebesar $62,1 \%$ dipengaruhi oleh variabel lain diluar model penelitian. Penilaian layak tidaknya model regresi data panel dengan pendekatan efek random dalam menjelaskan pengaruh variabel-variabel bebas CAR, TA, LDR, KAP, dan BOPO terhadap variabel terikat NPL dilihat dari nilai probabilitas F-stat. Nilai probabilitas F-stat yang lebih kecil dari tingkat kesalahan 5\% menunjukkan bahwa model tersebut layak digunakan untuk menjelaskan pengaruh variabel bebas terhadap variabel terikatnya.

Rasio kecukupan modal yang diproksi oleh CAR memiliki pengaruh yang signifikan terhadap kredit macet yang diproksi oleh NPL. Semakin tinggi rasio kecukupan modal, maka akan semakin meningkatkan NPL. Sebaliknya, semakin rendah rasio kecukupan modal, maka NPL juga akan semakin kecil. Setiap peningkatan $1 \%$ CAR maka akan meningkatkan NPL sebesar 0,06\%. Hal ini dikuatkan oleh penelitian Wardoyo dan Rusdiyanti (2009) serta Jusmansyah dan Sriyanto (2013) yang mengungkapkan bahwa CAR berpengaruh positif terhadap NPL. Pengendalian kredit macet dapat dimulai dari pengendalian rasio

Tabel 4. Uji Chow

\section{Redundant Fixed Effects Tests}

\section{Equation: FE}

Test cross-section fixed effects

\begin{tabular}{lccc}
\multicolumn{1}{c}{ Effects Test } & Statistic & d.f. & Prob. \\
\hline Cross-section F & 21,311096 & $(9 ; 295)$ & 0,0000 \\
Cross-section Chi-square & 155,272094 & 9 & 0,0000 \\
\hline Sumber
\end{tabular}

Sumber: data yang diolah (2015)

Tabel 5. Hausman Test

\section{Correlated Random Effects - Hausman Test}

Equation: RE

Test cross-section random effects

\begin{tabular}{cccc}
\hline Test Summary & Chi-Sq. Statistic & Chi-Sq. d.f. & Prob. \\
\hline Cross-section random & 3.360017 & 5 & 0,6447 \\
\hline
\end{tabular}

Sumber: data yang diolah (2015) 
kecukupan modal. Apabila Bank Umum ingin menurunkan kredit macet yang dimilikinya, dapat dilakukan dengan cara menekan rasio kecukupan modalnya.

Tinggi rendahnya aset yang dimiliki oleh Bank Umum tidak akan mempengaruhi kredit macetnya. Artinya besar kecil aset suatu Bank Umum tidak akan menyebabkan NPL Bank Umum tersebut menjadi bertambah atau berkurang. Hal ini juga mengindikasikan, bahwa ukuran bank (Bank Size) tidak menentukan kemampuan Bank Umum dalam mengelola kualitas kreditnya.

Besarnya jumlah kredit yang disalurkan (LDR) berpengaruh negatif terhadap kredit macet. Semakin tinggi kredit yang disalurkan maka akan mendorong berkurangnya NPL Bank Umum. Hasil ini dikuatkan oleh Soebagio (2005) yang menyatakan bahwa LDR memiliki pengaruh negatif terhadap NPL. Setiap kenaikan 1\% LDR maka akan menurunkan NPL sebesar 0,0122\%. Startegi meningkatkan LDR tentunya dengan mendorong penyaluran kredit. Menambah penyaluran kredit semakin menurunkan kredit macet dan membuka peluang untuk meningkatkan persentase kualitas kredit yang disalurkan.

Peningkatan kualitas aktiva produktif akan mendorong peningkatan NPL. Setiap kenaikan 1\% KAP akan mendorong peningkatan NPL sebesar 0,1925\%. Sebaliknya, penurunan $1 \%$ KAP akan mendorong penurunan NPL sebesar 0,1925\%. Kualitas aktiva produktif dipengaruhi oleh APYD dan atau total aktiva produktif. Penurunan APYD dapat dilakukan apabila Bank Umum ingin menekan kredit macetnya. Hal lain yang dapat dilakukan adalah meningkatkan kualitas aktiva produktifnya.Hal tersebut didukung Soebagio (2005) dan Jayanti dan Haryanto (2013) bahwa KAP berpengaruh positif terhadap NPL.

Kemampuan manajemen bank dalam mengendalikan biaya operasional terhadap pendapatan operasional dalam kegiatan operasionalnya berpengaruh signifikan terhadap penurunan kredit macet. Semakin efisien Bank Umum dalam kegiatan operasionalnya, yang ditunjukkan oleh semakin kecil nilai BOPO, maka semakin kecil pula NPL Bank Umum tersebut. Setiap kali Bank Umum dapat meningkatkan efisiensinya sebesar $1 \%$ maka secara otomatis akan menurunkan nilai kredit macet $0,0399 \%$. Hal ini juga mengindikasikan kegagalan Bank Umum dalam mengefisiensikan kegiatan operasionalnya akan mengakibatkan tumbuhnya kredit atau pembiayaan bermasalah.

Sebagaimana yang dipaparkan oleh Jayanti dan Haryanto (2013), kemungkinan gagal bayar dari debitur dapat menimbulkan biaya tambahan atas penagihan yang dikategorikan sebagai kerugian. Hal ini juga didukung oleh Wardoyo dan Rusdiyanti (2009) serta Ngadlan dan Riadi (2010) yang mengatakan semakin kecil rasio BOPO berarti semakin efisien biaya operasional yang dikeluarkan bank sehingga kemungkinan bank dalam kondisi bermasalah semakin kecil.

\section{SIMPULAN DAN SARAN}

Berdasarkan analisa dan pengolahan data yang telah dijelaskan mengenai analisis faktor yang memengaruhi NPL pada Bank Umum di Bursa Efek Indonesia (BEI) pada tahun 2007 sampai dengan 2014, dapat disimpulkan beberapa hal sebagai berikut: (1) Capital Adequacy Ratio (CAR) memiliki pengaruh signifikan positif terhadap NPL pada Bank Umum di Bursa Efek Indonesia; (2) Total aset tidak berpengaruh signifikan terhadap NPL pada Bank Umum di Bursa Efek Indonesia; (3) Loan to Deposit Ratio (LDR) berpengaruh signifikan negatif terhadap NPLpada Bank Umum di Bursa Efek Indonesia; (4) Kualitas Aktiva Produktif (KAP) memiliki pengaruh signifikan positif terhadap NPL pada Bank Umum di Bursa Efek Indonesia dan (5) Biaya Operasional Pendapatan Operasional (BOPO) berpengaruh signifikan positif terhadap NPL pada Bank Umum di Bursa Efek Indonesia.

Hasil penelitian ini diharapkan dapat memberikan informasi mengenai faktor-faktor yang dapat mempengaruhi NPL dan cara mengendalikan NPL sehingga perbankan dapat 
menjaga rasio NPL net agar tetap dibawah $5 \%$, hal ini untuk mempertahankan kondisi tingkat kesehatan bank tersebut. Selanjutnya, bagi investor yang akan melakukan investasi dananya melalui Bursa Efek Indonesia di sektor perbankan, selain melihat faktor-faktor yang mempengaruhi NPL sebaiknya juga melihat informasi lain yang tercantum pada laporan keuangan bank tersebut untuk mengetahui kondisi suatu bank, sehingga dapat dijadikan pertimbangan bagi investor untuk membuat keputusan dalam memilih bank tempat menyimpan kelebihan dana yang dimiliki investor atau nasabah. Penelitian ini diharapkan dapat dijadikan acuan untuk penulis berikutnya serta dapat meneliti faktor-faktor lain yang mempengaruhi NPL pada bank umum di Bursa Efek Indonesia

\section{DAFTAR PUSTAKA}

Abedalfattah, Z. A \& Faris, N. A. 2013. Analysis the Determinants of Credit Risk in Jordanian Banking: An Empirical Study. Management Research and Practice. 5 (3) : 21-30.

Akinlo, O \& Emmanuel, M. 2014. Determinants of Non-Performing Loans in Nigeria. Accounting ఓ Taxation. 6 (2): 21-28.

Bank Indonesia. 2013. Laporan Tahunan Bank Indonesia Tahun 2013. Bank Indonesia. . 15 Oktober 2014. Data Emiten . hlm. 16

Chikoko, L, Mutambanadzo, T \& Vhimisai, T. 2012. Insights on Non-Performing Loans: Evidence from Zimbabwean Commercial Banks in a Dollarised Environment (2009-2012). Journal of Emerging Trends in Economics and Management Sciences. 3 (6): 882-886.

Dendawijaya, L. 2009. Manajemen Perbankan. Edisi Kedua. Jakarta: Ghalia Indonesia.

Diyanti, A \& Widyarti, E. T. 2012. Analisis Pengaruh Faktor Internal dan Eksternal terhadap terjadinya Non-Performing Loan (Studi Kasus pada Bank Umum Konvensional yang Menyediakan Layanan Kredit Pemilikan Rumah Periode 2008-2011). Diponegoro Journal of Management. 1 (4) : 290-299.

Hapsari, E. 2012. Kekuatan Rasio Keuangan dalam memprediksi kinerja keuangan. Jurnal Dinamika Manajemen. 3 (2).
Jayanti, K. D \& Haryanto, A. M. 2013. Analisis Faktor-Faktor yang mempengaruhi NonPerforming Loan Studi pada Bank Umum Konvensional yang Go Public di Indonesia periode 2008-2012). Diponegoro Journal of Management. 2 (3): 140-150.

Jusmansyah, M \& Sriyanto, A. 2013. Analisis Pengaruh CAR, BOPO dan ROA terhadap Non Performance Loan. Jurnal Akuntansi dan Keuangan. 2 (1): 46-65.

Kuncoro, M. 2009. Metode Riset Untuk Bisnis dan Ekonomi. Jakarta: Erlangga.

Loen, B \& Ericson, S. 2007. Manajemen Aktiva Pasiva Bank Non Devisa. Jakarta: PT Grasindo Jakarta.

Makri, V., Tsagkanos, A \& Bellas, A. 2014. Determinants of Non-Performing Loans: The Case of Eurozone. Panoeconomicus. 61 (2) : 193-206.

Nachrowi, D. N \& Usman, H. 2006. Penggunaan Teknik Ekonometrika. Jakarta: PT Raja Grafindo Persada.

Ngadlan \& Riadi, R.M. 2010. Pengaruh CAMEL terhadap Size pada Bank yang Listing pada Bursa Efek Indonesia. Pekbis Jurnal. 2 (3): 382-390.

Polodoo, V., Seetanah, B., Sannassee, R. V., Seetah, K \& Padachi, K. 2015. An Econometric Analysis Regarding the Path of Non Performing Loans- a Panel Data Analysis from Mauritian Banks and Implications for the Banking Industry. The Journal of Developing Areas. 49 (1): 53-64.

Priyatno, D. 2011. Buku Saku Analisis Statistik Data SPSS. Yogyakarta: Mediakom.

Riyadi, S. 2006. Banking Assets and Liability Management. Edisi Ketiga. Jakarta: Lembaga Penerbit Fakultas Ekonomi Universitas Indonesia.

Siamat, D. 2005. Manajemen Lembaga Keuangan. Edisi Kelima. Jakarta:Lembaga Penerbit Fakultas Ekonomi Universitas Indonesia.

Skarica, B. 2014. Determinants of non-performing loans in Central and Eastern European countries. Financial Theory and Practice. 38 (1):37-59.

Soebagio, H. 2005. Analisis Faktor-Faktor yang Mempengaruhi terjadinya Non-Performing Loan (NPL) pada BankUmum Konvensional. Tesis Tidak Dipublikasi. Semarang: Program Pasca Sarjana Universitas Diponegoro Semarang. 
Jurnal Dinamika Manajemen Vol. 6, No. 1, 2015, pp: 85-97

Sugiyono. 2009. Metode Penelitian Administrasi. Edisi Revisi. Bandung: Penerbit Alfabet.

Sugiyono. 2013. Metode Penelitian Kombinasi. Bandung: Penerbit Alfabet.

Vatansever, M \& Hepsen, A. 2015. Determining Impacts on Non-Performing Loan Ratio in Turkey. Journal of Applied Finance and Banking. 5 (1): 1-11.

Wardoyo, P \& Rusdiyanti, E. 2009. Faktor-Faktor yang mempengaruhi Non Performing Loan Bank Perkreditan Rakyat di Eks Karesidenan
Semarang. Jurnal Dinamika Sosbud. 11 (2): 127-139.

Widarjono, A. 2013. Ekonometrika Pengantar dan Aplikasinya. Edisi Keempat. Yogyakarta: UPP STIM YKPN.

Zaib, A., Farid, F \& Khan, M. K. 2014. Macroeconomic and Bank-Specific Determinants of Non-Performing Loans in the Banking Sector in Pakistan. International Journal of Information, Business and Management. 6 (2): 53-81. 